\title{
RESEARCH AND DEVELOPMENT IN WOUND MANAGEMENT PRODUCTS: A BRIEF REVIEW
}

\author{
SURYA GEETHA V, VISHAL GUPTA N, GOWDA DV*, KULKARNI PK
}

Department of Pharmaceutics, JSS College of Pharmacy, JSS Academy of Higher Education and Research, JSS Medical Institutions Campus, Sri Shivarathreeshwara Nagara, Mysore - 570 015, Karnataka, India. Email: dvgowda@jssuni.edu.in

Received: 08 November 2017, Revised and Accepted: 27 February 2018

ABSTRACT

Wound can be defined as any process which leads to the disruption of the normal architecture of a tissue. They may be closed or open, for example, abrasions, lacerations, avulsions, ballistic and excised, or surgical wounds. Successful wound care includes advancing patient local and systemic conditions in conjunction with a perfect injury healing condition. Numerous wide assortments of dressing materials are accessible both for extreme and persistent non-healing wounds. A wide range of wound healing products have been produced to impact this injury condition to give a nonpathogen, ensured, and clammy region for healing to happen. A perfect injury dressing ought to limit loss of protein, electrolytes, and liquids from twisted and to diminish pain and contamination alongside wound healing. More current products are as of now being utilized to supplant or enlarge different substrates in the injury healing period. There is a sharp complexity to prior routine of wound administration, where the injury is permitted to dry, yet the present advancement was to move forward to the idea of wet injury recovering. This review of the present wounding periphery in wound recovery occurs at the most recent utilizations of silver and the employments of negative pressure wound gadgets, propelled dressings and skin substitutes, and biologic injury items including development of hydrogels and hyperbaric oxygen as an aid in wound mending. With the advancement of accessible dressings, the objective is to locate the most proper methodology or blend of modalities to optimize wound healing.

Keywords: Topical wound care, Wet dressings, Sulfadiazine, Flamazine silvadene, Staphylococcus aureus.

(C) 2018 The Authors. Published by Innovare Academic Sciences Pvt Ltd. This is an open access article under the CC BY license (http://creativecommons. org/licenses/by/4. 0/) DOI: http://dx.doi.org/10.22159/ajpcr.2018.v11i6.23541

\section{INTRODUCTION}

Healing restores the cellular and anatomic continuity of an organism. It minimizes tissue damage and debris non-viable tissue and maximizes tissue perfusion and oxygenation; proper nutrition provides moist wound healing environment. Major events in the wound healing include inflammation, proliferation, and migration of connective tissue cells production of extracellular matrix including collagen synthesis, epithelial cell migration, and proliferation leading to reepithelialization and endothelial cell migration and proliferation leading to new vascularization of the wounded tissue [1]. In wound care, silver dressings increase efficiency with reduced side effects. Many of wound care products have been obtained from previous treatment of wound care, but some of them are new results of recent research studies. The present article will talk about around a few new advances in consume and wound care and the administration of wound care products. Originally, silver nanoparticles can be synthesized using various chemical and physical methods, but these approaches are not environmentally benign. Each method has advantages and disadvantages with common problems being cost, scalability, and wide size distribution [2], and decrease in the stability of the nanoparticles on application can be problematic since aggregation decreases the specific surface area lowering the antimicrobial and catalytic activity. To optimize the healing conditions by altering the wound, environment is made successful by new wound dressings. Skin substitutes are created by tissue engineering and biosynthesis which not only provides the efficient impermanent treatment of wounds but also alters the concept of injury organization. There are wounds not supporting to the other treatments, especially chronic wounds, which are treated with the growth factors and biologic substances [3].

\section{Tropical wound dressings}

Wound dressing can be classified as follows.

\section{Passive dressings}

Passive dressings are ones which does not have direct effect on injury, but the dressings have protective action. Passive dressings are simple products like gauze.

\section{Interactive dressings}

Interactive dressings are modern dressings that they interacts with wound bed where there is optimum environment at the wound surface interfaces. Scales in 1956 has explained for basic requirement of wound dressing where in earlier winter explained the basic principles of moist wound healing. The ideal wound dressing characterizes the ideal condition of wound healing in moist environment where the technology has expanded and developed the advanced wound management products and the moisture retentive property has given by moisture vapor transmission rate (MVTR). According to wound type, the dressing product can be selected by MVTR.

\section{Utilizing fat to help wound healing without scars}

This technique includes change of cells in wounds into fat cells. The hair and fat grew independently and not as autonomously. Hair follicles are changed over to encompassing fibroblasts to recover as a fat as opposed to staying as scar. That fat would not frame without the new hairs; however, once it does, the new cells are vague from the previous fat cells, giving the recuperated wound a characteristic look as opposed to leaving a scar. Scientists recognized that a component called bone morphogenetic protein was sending signal from fat to hair cells. As they inspected, the subject of what was sending the flag from the hair to the fat cells [3]. The fibroblasts were unequipped for turning into the other kind of cell; however the outcomes ensures that the change of injured cells to adiposes [4]. The reviews were led in both mouse and keloid cells developed in a culture.

\section{SILVER}

Silver has very broad spectrum with antimicrobial resistance with minimum toxicity and is used for treating for infections of earliest wounds documented in 69BC with latest techniques of antimicrobial prophylaxes [5]. Various silver containing items have been produced with wound mending property and least unfriendly impacts.

Silver particles limit to proteins and chlorides in the injury bed liquid which has antimicrobial activity [5]. As presented in 1968, silver was complexes to glycols and alcohols and consolidated with different 
anti-infection agents such as sulfadiazine [6]. While this it gives a hypothetical preferred standpoint by including the activity from the anti-microbial resistance contrasted and silver nitrate (1\% vs. 0.5\%) [7]. While the addition of propylene glycol is hypothetical since its addition causes reepthilisation, and psuedo scar formation and also bone marrow depletion [8]

\section{Negative pressure wound devices}

Negative pressure wound gadgets (NPWDs) have under come some of minor changes. The negative pressure wound devices are having high therapeutic value for wound healing which instills the liquids for the recurrent healing and having predictable post estimation with good wound healing properties [9]. NPWD is dealt with for intense injuries. In patients with intense harm, it is utilized as a part of delicate tissue damage some tainted injuries and wounds with some harmed tissues. The NPWD wipe has been put on critical structures such as vessels, nerves heart, and lungs [10]. In between the structure and wipe, silicone work must be set amid wound recuperating treatment. The NPWD terminations diminish the measurement and too volume that upgrades recreation [11]

Numerous perplexing injuries can be lessened by NPWD terminations. Entero cutaneous fistulas were at first a contraindication for NPWD conclusion. Injury patients experiencing harm laparotomy disorder are likewise being stalled by permitting open guts with the NPWD setup [12]. This gives brief scope, and all the more imperatively give an instrument to expulsion of intra-stomach sullying and exudates while assuaging instinctive edema [13].

Indeed, even ideal material, for example, orthopedic equipment, vascular manufactured join, or engineered work will create regeneration with the NPWD [14]. These structures are in a perfect world reproduced with defensive folds; however, skin joining tissue repair is a choice in patients that are not fold competitors [15].

\section{Advanced Dressings}

Bandage dressing is as yet the most normally utilized for doctor's facilities today, and new twisted comprehension and innovation have created propelled items in the body accomplish the perfect clammy, warm, secured wound mending condition. Plain cloth is reasonable, promptly accessible, and suitable for a substantial healing. Impregnated dressing enhances this by including zinc, iodine, anticipate drying up, and give no follower scope.

The procedure of autolysis is vital in wound care. In patricular conditions wound healing is also exposed to outer environments so that the patricular phagocyte relied can be obtained. These items extend from films, for example, DuoDERM, which are additionally occlusive yet give assimilation of exudates notwithstanding keeping up a wet situation for autolysis. For intense injuries, there is a scope of absorptive items including different hydrophilic froth dressings and hydrogels, which can assimilate up to 20 times their weight. In spite of the fact that these items are more costly than customary cloth, late reviews appear to show a general cost investment funds because of diminished work costs: Propelled dressings commonly are changed each 1-3 days, instead of bandage, which is frequently changed different times each day [16].

\section{Skin substitutes}

Recent advancements in wound healing therapy the most substantial problem associated was the larger skin surface area of patients. Auto unite is right now the favored alternative; however, in many occurrences, there is a lacking measure of tissue accessible for wound which blocks the utilization of auto unite [17]. Allograft and xenografts can give a brief scope choice, in regard to dismissal, and conceivable infection exchange, accessibility, and in addition social and moral contemplations.

Table 1: Summary of new anti microbial wound products

\begin{tabular}{|c|c|c|c|c|c|}
\hline Antibacterial & Mechanism & Advantage & Disadvantage & Use & Company \\
\hline Mupirocin (antibacterial) & $\begin{array}{l}\text { Wound infected with } \\
\text { Gram-positive that } \\
\text { prevents bacterial } \\
\text { protein and cell wall } \\
\text { synthesis }\end{array}$ & $\begin{array}{l}\text { Do not damage healthy } \\
\text { tissues }\end{array}$ & Cost effective & $\begin{array}{l}\text { Can be } \\
\text { applied } \\
\text { daily }\end{array}$ & - \\
\hline Retapamulin & $\begin{array}{l}\text { Inhibit bacterial } \\
\text { protein synthesis }\end{array}$ & $\begin{array}{l}\text { Effective against } \\
\text { mupirocin and } \\
\text { fucidin-resistant } \\
\text { bacteria }\end{array}$ & Cost effective & & Retrial (Ajanta Parma) \\
\hline $\begin{array}{l}\text { Silver-impregnated } \\
\text { dressings }\end{array}$ & $\begin{array}{l}\text { Deep burns, skin } \\
\text { sloughing, donor sites } \\
\text { and meshed skin grafts }\end{array}$ & $\begin{array}{l}\text { Effected for wounds } \\
\text { effected with } \\
\text { Gram-positive and } \\
\text { negative and as fungi }\end{array}$ & Costly & $\begin{array}{l}\text { Chine } \\
\text { every } 5 \text { to } \\
7 \text { days }\end{array}$ & $\begin{array}{l}\text { Act coat (Smith and } \\
\text { nephew), silver (data } \\
\text { Parma) actisorb (Jonson } \\
\text { and Jonson) }\end{array}$ \\
\hline Hydro gels & $\begin{array}{l}\text { Dry and painful } \\
\text { pressure sores stasis } \\
\text { ulcers }\end{array}$ & $\begin{array}{l}\text { Absorbent, occlusive } \\
\text { protection }\end{array}$ & $\begin{array}{l}\text { Opaque fluid } \\
\text { trapping }\end{array}$ & $\begin{array}{l}\text { Change on } \\
1-3 \text { days }\end{array}$ & $\begin{array}{l}\text { Intrusive gel (smith and } \\
\text { Nephew), solo site }\end{array}$ \\
\hline Enzymatic debridement & $\begin{array}{l}\text { For necrotic slough } \\
\text { wounds }\end{array}$ & $\begin{array}{l}\text { Digests only necrotic } \\
\text { tissues }\end{array}$ & $\begin{array}{l}\text { Papa in is } \\
\text { non-selective so } \\
\text { need of secondary } \\
\text { dressing }\end{array}$ & $\begin{array}{l}\text { Minimum } \\
\text { daily use }\end{array}$ & $\begin{array}{l}\text { Collagens santyl (Health } \\
\text { Port), Accuzyme, } \\
\text { debridace }\end{array}$ \\
\hline Growth factors & $\begin{array}{l}\text { In small non-healing } \\
\text { wounds }\end{array}$ & $\begin{array}{l}\text { Accolade healing of } \\
\text { wounds }\end{array}$ & $\begin{array}{l}\text { Not indicate in } \\
\text { necrotic wounds }\end{array}$ & $\begin{array}{l}\text { Tobeapplied } \\
\text { daily }\end{array}$ & $\begin{array}{l}\text { Permian (Dr. Reddy } \\
\text { lab) Eugraf (lupine) } \\
\text { Epigrof (Marksans) }\end{array}$ \\
\hline
\end{tabular}

Table 2: Example of wound care products

\begin{tabular}{ll}
\hline Wound care products & Examples \\
\hline Products which enhance epithelization & Hydrocolloids, hydrofoams, and growth factors \\
Products which prevent infection & Antimicrobials such as silver dressings, mupirocin, and retapamulin \\
Desloughing and debriding agents & Maggots, debridace, enzymes like papain, hydrocision \\
Products enhancing tissue formation & Hydrocolloids, alginates, hydrogels, VAC \\
Products preventing infection and enhancing granulation & Retapamulin, hydrogels, hydrocolloids, and enzymes \\
\hline
\end{tabular}


Skin substitutes are the one which are well established treatment with higher scope of therapeutic benefits for wound healing. The fundamental restriction of these items is their cost. Biobrane is an impermanent dressing made out of weaved nylon and covered with porcine polypeptides [18]. Ponders have demonstrated it to be as adequate as silver sulfadiazine in twisted mending without the recurrence of dressing changes [19]. It is utilized as a dressing in shallow consumes that do not require skin joining or as a brief cover for extracted consumes before uniting [20]. A few reviews have indicated it to be better than anti-microbial creams or silver sulfadiazine as far as recuperating time, contaminations, and scar arrangement, particularly on facial consumes [21].

The fibroblasts deliver glycosaminoglycans, development elements, to bolster wound healing [22]. It is transitory or changeless cover utilized for extracted wound healing and also venous ulcers and weight ulcers. Results indicate it to be practically identical to allograft for wound contamination [23].

Allograft is made out of an outermost layer of allergenic neonatal keratin cells prepuce on bilayered sort I ox-like collagen that is utilized as an extra covering to auto join, giving quickened mending times [24]. It is likewise utilized alone in ceaseless injury ulcers, indicating expanded recuperating times when contrasted with controls [25]. The pore is intended to permit relocation of particular endothelial cells and fibroblasts [26]. As the injury mends, the silicone sheet is expelled and a thin auto unite is joined onto the endodermis to finish the injury scope [27]. It is shown for extracted profound halfway and fullthickness consume wounds [28]. Furthermore, in no consume wounds, it is utilized as a part of complex traumatic delicate tissue reproduction over uncovered ligaments, joints, and bones [29]. A review follow-

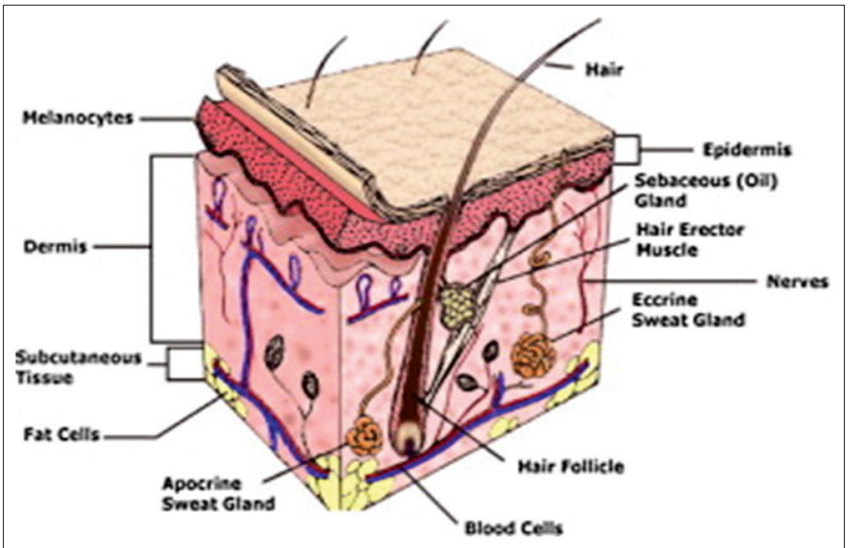

Fig. 1: Anatomy of skin up shows astounding makeup than autologous skin uniting and with phenomenal versatility when set over joints [30]

\section{Growth factors and biologic wound products}

Biologically injury products have been a territory of enormous development as our comprehension of the points of interest of the injury recuperating reaction has expanded. In typical injury recuperating, there is a systematic, unsurprising succession going through the provocative, expansion, and renovating/development stages [31]. The biologic injury items plan to quicken recuperating by increasing or balancing these provocative middle people. While the lion's share of examinations on these substances are little laboratory contemplates, there are some evident advantages seen in clinical examinations. They basically influence the early phases of wound mending including starting vasoconstriction and later vasodilatation, vascular penetrability, and provocative cell chemo taxicabs and bond [32]. The most surely understood is prostaglandin E1 which represses platelet and neutrophil initiation, lessens blood thickness, and empowers plasminogen activator that causes vasodilatation by unwinding vascular smooth muscle. Due to this capacity to balance irritation and vasodilator, its utilization in interminable vascular ulcers has been assessed with some noteworthy reduction in size and recuperating time contrasted with controls [33]. Cytokines had direct effect causing skin irritation by affecting haemopoietuc cells and incorporate chemokines, lymphocytes, monokines, interleukins, state invigorating elements, and interferon. A few of these have been contemplated. Its belongings are to empower neutrophils and fibroblasts and increment vascular endothelial growth factor generation, rendering it an exceptionally encouraging particle in wound mending [33]. There are many changes in treatment of wound healing for the patients with static skin irritants and having some foot ulcers [34].

Development components animate for the most part fibroblasts and keratinocytes by means of transmembrane glycoprotein [35]. They have been concentrated more than whatever other biologic injury supplements. They are isolated into five superfamilies, the most known being the platelet-inferred development components [36]. Patients were treated with rhPDGF or fake treatment for up to 20 weeks in this forthcoming randomized two-fold visually impaired review. The rhPDGF aggregate demonstrated a measurably huge higher rate of patients that accomplished injury recuperating, $48 \%$ versus $25 \%$, and in addition, a more prominent diminishment in wound size [37]. Extra reviews have affirmed expanded chances of wound mending and diminished rates of removal in diabetic foot ulcers and also quickened twisted recuperating in stomach wound division and illuminated injuries [38].

\section{Hyperbaric Oxygen}

Hyperbaric oxygen treatment includes setting up in a fixed chamber where $100 \%$ oxygen is pressurized which is initially intended for use

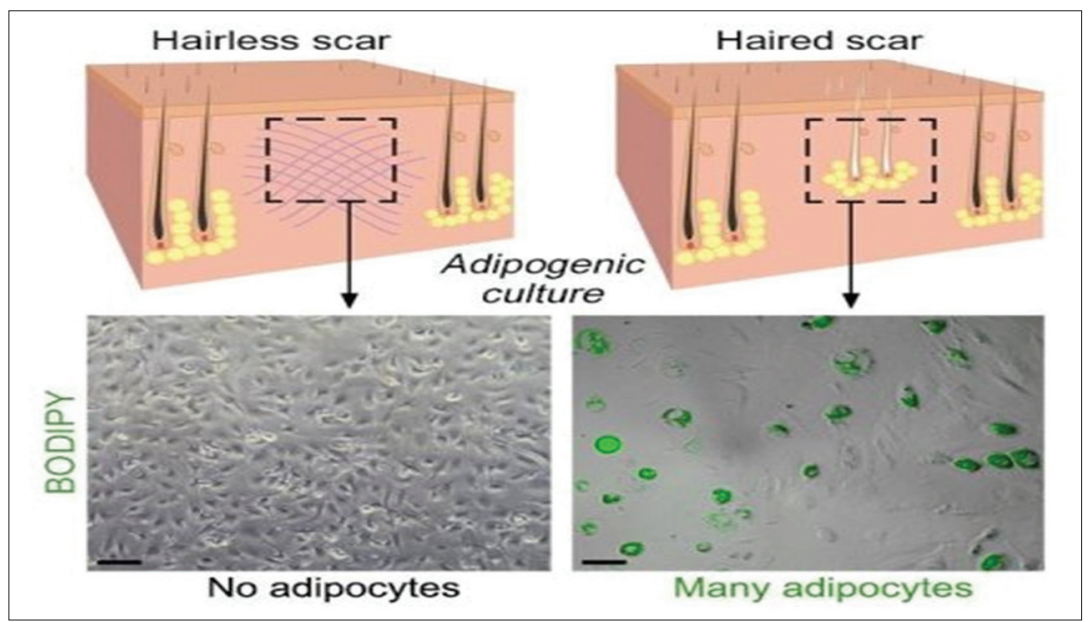

Fig. 2: Typical myofibroblast cells 
in uncompressed sickness in remote ocean jumpers, and it has signs for the use for carbon monoxide harming, squash wounds, disorder, intense radiation harm, traded off skin unites, diseases with nonaerobic life forms, and headstrong osteomyelitis. Likewise, there are some particular signs for HBO treatment in constant injuries [39].

The component of activity of hyperbaric oxygen is not plainly seen, but rather a few reviews are at present continuous [40]. Starting speculations concentrated on increments in accessibility at cellular level [41]. With regard to expansion from plasma to tissues there are some modifications in the treatment at cellular level because of expanded cells which causes vasoconstriction and advancement of fluid retention into the wounds. This impact ordinarily goes on for a few hours after the treatment has finished [42]. Angiogenesis alludes to the ingrowths of cells into an injury from the encompassing tissue [43]. It is the procedure whereby forebear undifferentiated cells separate and change a vascular system inside an injury.

Neovascularization is needy on fundamental procedures. They associate with proper nearby twisted variables and cytokines, to be specific, stoma cell-determined element (SDF)- $1 \alpha$, so as to empower vasculogenesis. They have been appeared to have diminished numbers and weakened capacity of bone marrow determined and impeded EPC enrolment. It is appeared to animate EPCs and undeveloped cell discharge from bone marrow both by expanded cell expansion inside the marrow and also by quick assembly by means of network metalloprotease instruments.

Beginning, it is demonstrated the diminished size of interminable lower-furthest point wounds in insulin-subordinate diabetics. In 2014, assessment of contrasting HBO with no-HBO treatment, foot ulcers, and the outcomes demonstrated a critical decline in the rates of significant

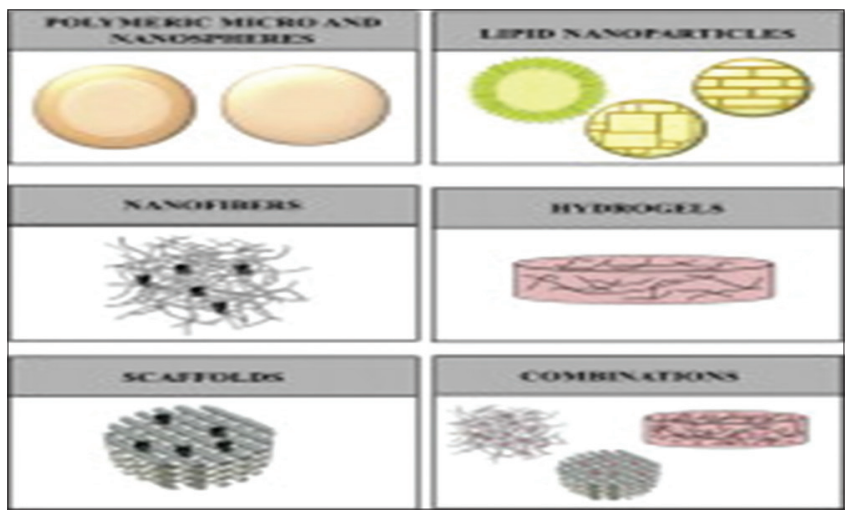

Fig. 3: Current marketed medications based on growth factors removals and also an expansion in the quantity of wounds that stayed mended 1-year post-treatment [44]. The fifth investigation of 16 patients demonstrated a reduction in the measure of venous ulcers at a month and a half. An extra review looking at lower-furthest point wounds treated by HBO, standard injury mind, development consider treatment, or HBO in addition to development calculate treatment demonstrated a critical increment in recuperating at 2 months in the HBO gather contrasted with the development figure bunches, with no extra advantage in addition to development calculate aggregate. This two-fold fake treatment controlled review looked at between Wagner review 2, 3, or 4 ceaseless ulcers treated with hyperbaric oxygen [45]. This review discovered measurably noteworthy change in healing. In examination, the biggest contrast in recuperating rate was seen following 9 months. This compares with a past RCT examination, demonstrating no critical distinction in HBO-treated gatherings at a month and a half, however accomplishing factual centrality in twisted mending at 1 year. [46].

\section{Foam}

Foam dressings are very permeable polyurethane dressings, accessible as cushions, sheets, and depression dressings. They make a moist situation and give warm protection to the injury. They are no follower, simple to apply, and evacuate and are implied for exceedingly oozing injuries. They can be layered in blend with different materials with overlying pressure wraps. The liquid ingestion limit differs with froth thickness; hence, they might be utilized for their padding impact yet they are not a substitute for weight assuaging gadgets. As far as ulcer mending, they have been discovered tantamount to hydrocolloids as per some studies [47]. Foams are used where they generally deliver the drug on the topical layers of the skin.

\section{Effect of a sustained silver-releasing foam dressing on ulcers with} delayed healing

Munter and Russell led a review in 2016 and concentrated the impact of maintained silver discharging froth dressings on ulcers with deferred healing. Lesser decrease in exudates level and more positive injury advance was accomplished with the silver froth. Also the sustained silver releasing dressings has high usage in the market. All distinctions were factually noteworthy $(\mathrm{p}<0.05)$. The silver froth dressing beats the greater part of the other dressing classifications including sodden injury recuperating items and other silver dressings [48]

\section{Hydrocolloids}

Hydrocolloids are made out of gelatine, pectin as well as carboxymethylcellulose and fill in as occlusive dressings. They are impervious, microscopic organisms, and however porous to water vapor [49]. They are not demonstrated for blood vessel contaminated or vigorously oozing injuries as a result of danger of per wound

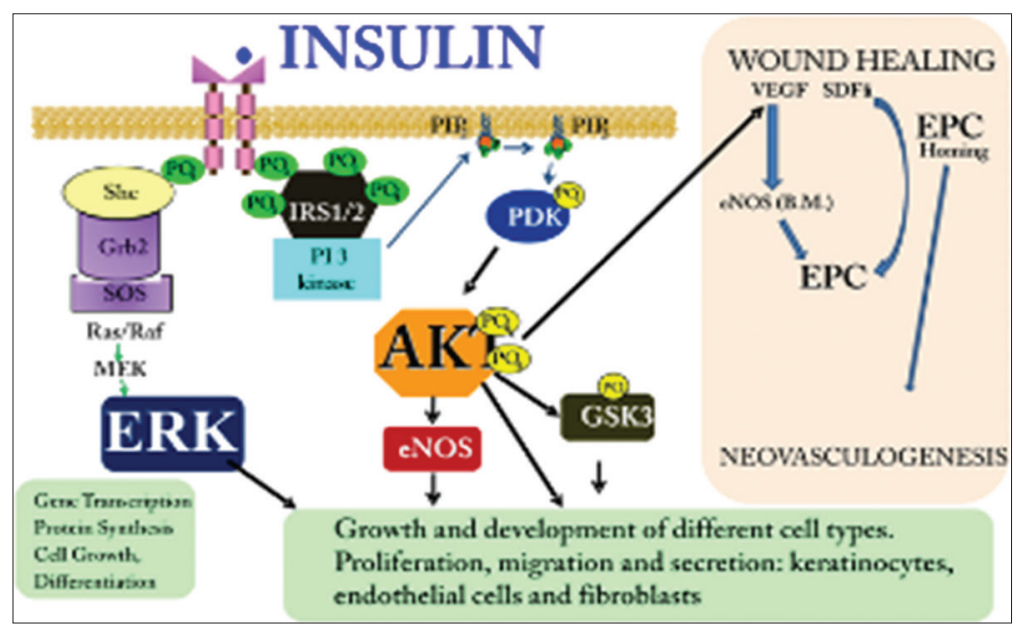

Fig. 4: Effect of insulin on cellular and molecular mechanisms of wound healing in diabetic patients 
maceration. Another drawback of the treatment is their inclination to deliver rancid exudates, which can be confused for disease [50].

\section{Development of novel peroxide-based antimicrobial hydrocolloid for wound dressings}

The capacity of the peroxide-containing hydrocolloids to restrain the development and improvement of wound pathogens was considered. Methicillin-resistant Staphylococcus aureus (MRSA, ATCC\# BAA-44), Acinetobacter baumannii (AB, ATCC\# 19606), Escherichia coli (EC, ATCC\# 8739), and Staphylococcus epidermidis (SE, ATCC\# 12228) were utilized for standard methods. All wounds are of course identical at inception. By days 5 through 7, the hydrocolloid sample groups show healthy granulation tissue [51]. while the silver dressing and the nonadherent gauze show margins featuring Escher and dry desiccated tissue - each signs of impediments to optimal healing. In days 10 through 14, we visually observe almost complete healing under the hydrocolloids. The non-adherent gauze controls appear to retain regions that are nonepithelial zed with eschew [52]. The silver dressings appear to feature black Escher consistent with silver deposits. Overall, the analytical measures confirm observations that the hydrocolloids appeared to have slightly faster wound healing as measured by area than did the control and silver groups [53].

\section{Hydrogels}

Hydrogels are polymers, impregnated clothes, or sheet dressings. The presence of water content does not permit them to retain a huge measure of exudates and cannot be utilized on overwhelming oozing injuries. They are delicate yet powerful debriding activity by unabsorbed necrotic tissue and expelling it and not harming sound tissue and retaining bog and exudates. They diminish torment in light of their cooling impact, are non-cement, fill dead spaces, and are anything but difficult to apply and evacuate. They are most appropriate for dry injuries or those with insignificant exudates. Be that as it may, they require an optional dressing.

\section{Skin cells "crawl" together to heal wounds treated with unique} hydrogel layer

Explore group drove by Milica Radisic utilizes their licensed peptide to close non-recuperating unending injuries brought about by diabetes peptide-hydrogel biomaterial prompts skin cells to "creep" toward each other, shutting ceaseless, non-mending wounds regularly connected with diabetes, for example, bed bruises and foot ulcers. Most medicines for endless injuries included applying topical salves that advance the development of veins to the region. Be that as it may, in diabetic patients, vein development is restrained, making those medications incapable. Radisic and her group have been working with their uncommon peptide - called QHREDGS or Q-peptide for short - for very nearly 10 years [54]. They knew it advanced survival of a wide range of cell sorts, including undeveloped cells, heart cells, and fibroblasts.

\section{Transparent films}

Transparent films are strengthen, penetrable, polyurethane layer dressings that change in shape and arrangement. They allow water vapor, and climatic gasses to cross yet are impermeable to microorganisms. Since these are transparent, injuries can be reviewed without evacuating. These adaptable and effortless films are perfect for joints and hand wounds. They are utilized on insignificant exudates and joins and mean to secure other injury dressings.

\section{A simple route to develop transparent doxorubicin-loaded} nanodiamonds/cellulose nanocomposite membranes as potential wound dressings

The goal of this review is to create transparent permeable cellulose films with controlled arrival of doxorubicin which were manufactured by insulating tape throwing strategy from scattering which is homogeneous in $7 \mathrm{wt} \% \mathrm{NaOH} / 12 \mathrm{wt} \%$ urea watery arrangement. By altering the content, different nanocomposite films were got [55]. The properties of the layers have been examined by filtering electron microscopy (SEM), Fourier change infrared spectroscopy (FTIR), X-beam diffraction (XRD), differential checking calorimeters (DSC), ductile tests, and water misfortune examinations [56].

\section{Debridement enzymatic debridement}

Collagenase helps in processing necrotic tissue without harming solid tissue [57]. However when acquired in organic form papaya organic product, separates cysteine deposits in proteins yet is no specific and is related with extreme provocative reaction and breakdown of practical bits of wound bed, in this manner related with significant pain [57]. Urea is joined to build its proteolytic activity, for example, Debridace.

\section{High-pressure water irrigation}

High-pressure water system is viable in expelling microbes, particulate matter, and necrotic flotsam and jetsam from the injuries, accordingly bringing down the rate of disease contrasted with low weight irrigation [58]. The main thought is a danger of microbes crashed into delicate tissue by the elevated weight. It is especially valuable in weight injuries and joint spaces and in tight tissues. It is shown for use in injuries and profound consumes likewise [58]. Since it safeguards the reasonable dermal tissue, it permits fast twisted recuperating with better healing.

\section{Biodebridement of medicated larvae (maggot therapy)}

The act of utilizing larvae has been around for a considerable length of time. As of late, there is a recovery of their utilization in the light. The necrotic material of bottle flies has been utilised as a part of ulcer treatment which is essential in wound healing. Their emissions contain proteolytic proteins, which processes just necrotic flotsam and jetsam and bog and furthermore catalysts which are bactericidal compelling against MRSA and b-hemolytic streptococcus yet do not bother ordinary host tissue [59]. The specific therapy can be accomplished inside 2 days. Hatchlings are left set up for 3 days, however, if there is an increment in agony in light of progress in wound $\mathrm{pH}$. Be that as it may, in spite of them, it is starting to build up a perceived part in wound therapy [60].

\section{Negative pressure wound therapy}

Negative weight wound treatment (NPWT) or vacuum-helped conclusion (VAC) has assumed a noteworthy part as a scaffold to reproduction. It is a critically demonstrated headway in treatment advances dynamic injury recuperating at the primary level of injury. Weight utilized is negative weight or sub climatic weight in a consistent or discontinuous manner [61]. The irregular negative weight is conveyed at twisted site through a permeable dressing, which applies mechanical powers known as large-scale strain (physical reaction) and smaller scale strain (natural reaction) and accordingly evacuates exudates by an electromechanical pump.

Comparison of negative pressure wound therapy using vacuumassisted closure with advanced moist wound therapy in the treatment of diabetic foot ulcers

In 2016, a review conducted by peter blumme and payne for the therapy of diabetic ulcers and ultimate healing characterised by skin epithelization. Patients were arbitrarily doled out to either NPWT (VAC) and got standard off-stacking treatment as required [62]. The runs assessed therapy of ulcer termination was by any methods. Patients whose injuries accomplished ulcer termination were taken after at 4 and 8 months. Each review included conclusion evaluation by wound assessment.

\section{Growth factors}

Development variables are actually occurrence proteins in the body which control many key cell exercises amid ordinary tissue repair prepare. Thus, there is inadequacy of development calculating the injury overnight boarding house cells which are captured in the cell cycle accordingly influencing the recuperating procedure in constant injury [62].

Different reviews have indicated the helpful impact of elements such as recombinant human platelet-inferred development consider (rhPDGF), fibroblast development calculate, granulocyte - macrophage settlement animating components, and epidermal development figure (EGF) either alone or in mix in quickening recuperating in perpetual wounds [63]. PDGF and EGF are the main topical development considering affirmed by USFDA for the treatment of perpetual injuries. PDGF advances 
chemostrategy enrolment and multiplication of cells required in wound repair. EGF additionally controls cell multiplication, movement, and separation through authoritative to receptor kinesis' on target cells and initiates angiogenesis.

\section{Advances in drug delivery systems (DDSs) to release growth} factors for wound healing and skin regeneration

Advances in medication conveyance frameworks (DDSs) to discharge development variables (GFs) speak to an awesome chance to grow new treatments or improve the viability of accessible restorative treatments [63]. They are especially important in testing human services issues, for example, wound recuperating an. Hence, they have been widely considered to enhance in vivo reconciliation of DDSs, to improve the bioactivity of the discharged medications, and to convey bioactive atoms in a confined and way. Along these lines, this audit displays a review of DDSs to discharge GFs for skin recovery, especially accentuating on (1) small scale and nanospheres, (2) lipid nanoparticles, (3) hydrogels, and (4) frameworks. Moreover, the study condenses the present creature models accessible for concentrate wound mending and the scientific trial and promoted meds in light of GF organization showed for incessant injury after medication [64].

\section{Skin substitutes}

As of late, a wide exhibit of naturally dynamic material and skin substitutes have been produced which address the different difficulties experienced amid wound mending. They as dressings, which shield twisted from liquid misfortune and disease, and others are being used as inserts that supplant lattice atoms or convey different development variables to get ready bed for changeless skin scope.

Soluble epoxies hydrolyze inhibition and epoxyeicosatrienoic acid treatment improve vascularization of engineered skin substitutes Antilogous designed skin substitutes involved keratinocytes and fibroblasts can fill in as an adjunctive treatment for extracted consumes. In the immunodeficient mice the surgical injuries were fulfilled only by the skin substitutes. Mice were treated with the sEHI 1-trifluoromethylphenyl-3-(1-propionylpiperidin-4-yl) urea [65]. The outcomes propose that $\mathrm{sEH}$ restraint can build vascularization of built skin joins after transplantation, which may add to upgraded engraftment and enhanced treatment of full-thickness wounds.

\section{Collagen}

Collagen, out of the numerous subtypes, sort I is generally found in wound healing tissues. Perpetual injuries are presently enhanced twisted mending by setting out a lattice where new tissue and pulls in cells fundamental for recuperating. The fibroblasts and macrophages furthermore give a brief platform to permit in development of tissue [66]. The human, porcine, or ox-like starting point are accessible as molecule or sheet shape. They assimilate twisted exudates to frame a delicate biodegradable gel over the injury surface, which keeps up wound dampness.

\section{Topical insulin}

Using insulin topically has been around for a considerable length of time going back to 1960s (greenway) [66]. From that point forward, there have been many trials on creatures and additionally people yet the handiness of insulin in wound mending still stays theoretical and defense issues still must be tended to [67].

Topical insulin in blend with zinc in creature ponders has appeared to mend wounds speedier. It controls wound fiery reaction by animating expansion and movement of macrophages and keratinocytes in neighboring tissues [68].

Topical insulin accelerates wound healing in diabetes by enhancing the AKT and ERK pathways

The impact of it was likewise examined in proteins required in insulin flagging. Comes about demonstrated that the blunted increment in
IRS-1, SHC, AKT, and ERK1/2 saw in diabetic patients was totally switched after treating with topical insulin downstream of AKT, two flagging proteins are essential for wound mending: GSK3 $\beta$ and eNOS. After topical administration of insulin for the diabetic patients [69] the protien levels of eNOS and GSK3 where the skin has been injured is completely healed or diminished which is shown in the Fig. 5.

\section{Future of wound care}

Motivate the alternatives, impervious to treatment, and an assortment of advanced systems are explored. These incorporate tissue building strategies such as immature microorganisms and quality treatment for accomplishing wound conclusion [71]. Undifferentiated organisms can relocate to the site of harm or aggravation, take an interest in recovery of harmed tissue, fortify multiplication and separation of occupant descendant cells, emitting development variables, renovating network, expanding angiogenesis, restraining scar arrangement, and enhancing elasticity of the injury. ADSC alone or with platelet-rich plasma is a promising apparatus in ceaseless injury mending; however, the conveyance systems and finish impact should be examined and refined. As of late, undifferentiated organism based skin designing alongside quality recombination speaks to an option appliance.

Current medication conveyance techniques cannot control loss of medication action because of physical hindrance. Hence, to advance the conveyance of elements for most extreme adequacy, a subatomic hereditary qualities approach is being inquired about in which hereditarily changed cells orchestrate and convey the coveted development figure, a period managed and privately confined way to the injury site to advance injury mending. Their activity might be additionally reinforced by embedding them in a biomaterial framework which advances cell grip, multiplication, relocation, and separation. Initial microorganisms may develop as an energizing focus for quality move in tissue repair. In the event that undifferentiated organisms could be told to separate into one specific heredity and practically incorporate into harmed tissue condition, they can supplant cells that have been lost [71]

\section{CONCLUSION}

Wound administration has made fast advances in the course of the most recent 25 years and with increment in the comprehension of the science of context non-recuperating wounds; this progression is probably going to proceed. In the race to use the more up to date wound medications, clinicians ought not to disregard the rudiments of good twisted care on the off chance that they need to get most extreme advantages from these advancing treatments. Clear rules focussing on the standards of compelling injury bed arrangement have been laid and they must be taken after to guarantee powerful patient result with the utilization of more up to date wound care substance. Dressing determination relies on the expert's exceptional appraisal of the injury and his insight into how to give this ideal injury mending condition using present-day intuitive dressings. The plenty of wound care items in the market has brought about specialist's utilizing a blend of items, which may make the treatment exceptionally costly. Be that as it may, regardless of the possibility that a specific dressing is costly yet advances wound mending quickly prompting the demand clinical outcomes, it can be judged to be practical.

\section{REFERENCE}

1. Santram L, Gautam PV. Relevance and perspectives of experimental wound models in wound healing research. Asian J Pharm Clin Res 2017; 10:57-62.

2. Priyadarshni CK, Mahalingam PU. Antimicrobial and anticancer activity of silver nanoparticles from edible mushroom: A review. Asian J Pharm Clin Res 2017;10:37-40.

3. Mostafalu P, Akbari M, Alberti KA, Xu Q, Khademhosseini A, Sonkusale SR. A toolkit of thread-based microfluidics, sensors, and electronics for 3D tissue embedding for medical diagnostics. Microsyst 


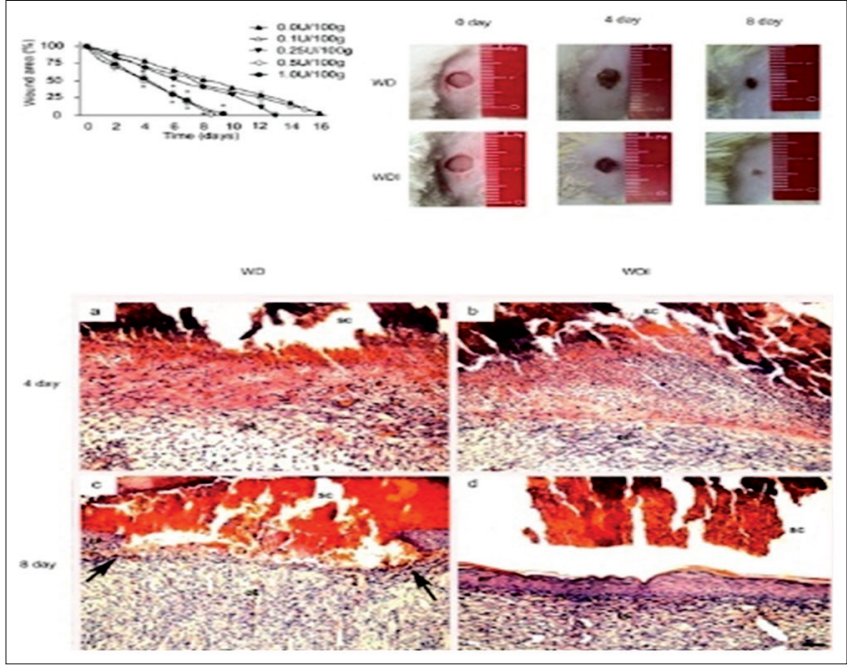

Fig. 5: Macroscopic wound closure in diabetic rats treated with different concentrations of insulin cream [70]

Nanoeng 2016;39:317-22

4. Mchugh GL, Moellering R, Hopkins C, Swartz M. Salmonella typhimurium resistant to silver nitrate, chloramphenicol, and ampicillin. Lancet 2012;305:235-40.

5. Demidova-Rice TN, Hamblin MR, Herman IM. Acute and impaired wound healing: Pathophysiology and current methods for drug delivery, Part 1: Normal and chronic wounds: Biology, causes, and approaches to care. Int J Adv Skin Wound Care 2012;25:304.

6. Suzuki Y, Nishimura Y, Tanihara M, Suzuki K, Nakamura T, Shimizu Y, et al. Evaluation of a novel alginate gel dressing: Cytotoxicity to fibroblasts in vitro and foreign body reaction in pig skin in vivo. J Biomed Mater Res A 2010;39:317-22.

7. Brem H, Balledux J, Bloom T, Kerstein MD, Hollier L. Healing of diabetic foot ulcers and pressure ulcers with human skin equivalent: A new paradigm in wound healing. Arch Surg 2000;135:627-34.

8. Sprung P, Hou Z, Ladin DA. Hydrogels and hydrocolloids: An objective product comparison. Ostomy Int J Wound Manage 2010;44:36-42.

9. Cianfarani F, Tommasi R, Failla CM, Viviano MT, Annessi G, Papi M, et al. Granulocyte/macrophage colony stimulating factor treatment of human chronic ulcers promotes angiogenesis associated with de novo vascular endothelial growth factor transcription in the ulcer bed. Br J Dermtol 2006;154:34-41

10. Da Costa RM, Jesus FM, Aniceto C, Mendes M. Randomized, double blind, placebo controlled, dose ranging study of granulocyte macrophage colony stimulating factor in patients with chronic venous leg ulcers. J Wound Repair Reg 2011;7:17-25.

11. Cruciani M, Lipsky BA, Mengoli C, De Lalla F. Are granulocyte colonystimulating factors beneficial in treating diabetic foot infections? Diabetes Care 2005;28:454-60

12. Bennett SA, Birnboim HC. Receptor-mediated and protein kinase-dependent growth enhancement of primary human fibroblasts by platelet activating factor. Mol Carcinog 2012;20:366-75.

13. Steed DL. Clinical evaluation of recombinant human platelet-derived growth factor for the treatment of lower extremity ulcers. Ind J Plastic Reconstruct Surg 2006;117:143S-9S.

14. Margolis DJ, Bartus C, Hoffstad O, Malay S, Berlin JA. Effectiveness of recombinant human platelet derived growth factor for the treatment of diabetic neuropathic foot ulcers. J Wound Repair Reg 2005;13:531- 6 .

15. Hom DB, Manivel JC. Promoting healing with recombinant human platelet derived growth factor-bb in a previously irradiated problem wound. Laryngoscope 2003;113:1566-71

16. Langemo DK, Black J. Pressure ulcers in individuals receiving palliative care: A national pressure ulcer advisory panel. Adv Skin Wound Care 2010;23:59-72.

17. Boykin JV. Hyperbaric oxygen therapy: A physiological approach to selected problem wound healing. J Wound Repair Reg 2005;13:531-6.

18. Bauer SM, Bauer RJ, Velazquez OC. Angiogenesis, vasculogenesis, and induction of healing in chronic wounds. J Vasc Endovasc Surg 2005;39:293-306.

19. Velazquez OC. Angiogenesis and vasculogenesis: Inducing the growth of new blood vessels and wound healing by stimulation of bone marrow-derived progenitor cell mobilization and homing. J Vasc Surg 2007;45:A39-47.

20. Bradley M, Cullum N, Nelson EA, Petticrew M, Sheldon T, Torgerson D. Systematic reviews of wound care management:(2) dressings and topical agents used in the healing of chronic wounds. Int J Wound Care 2011;3:305-56.

21. Rubin JR, Alexander J, Plecha EJ, Marman C. Unna's boot Vs polyurethane foam dressings for the treatment of venous ulceration: A randomized prospective study. Arch Surg 2009;125:489-90.

22. Kannon GA, Garrett AB. Moist wound healing with occlusive dressings. J Dermtol Surg 2013;21:583-90

23. Agren MS. Four alginate dressings in the treatment of partial thickness wounds: A comparative experimental study. Br J Plastic Surg 2009;49:129, 34

24. Doyle JW, Roth TP, Smith RM, Li YQ, Dunn RM. Effect of calcium alginate on cellular wound healing processes modeled in vitro. J Biomed Mater Res A 2011:32:561-8

25. Suzuki Y, Nishimura Y, Tanihara M, Suzuki K, Nakamura T, Shimizu Y, et al. Evaluation of a novel alginate gel dressing: Cytotoxicity to fibroblasts in vitro and foreign body reaction in pig skin in vivo. J Biomed Mater Res A 2010;39:317-22

26. Sprung P, Hou Z, Ladin DA. Hydrogels and hydrocolloids: An objective product comparison. Ostomy Int J Wound Manage 2010;44:36-42.

27. Banks V, Hagelstein S, Thomas N, Bale S, Harding KG. Comparing hydrocolloid dressings in management of exuding wounds. Br J Nurs 2013;8:6406.

28. Sarabahi S. Recent advances in topical wound care. Ind J Plastic Surg 2012;45:379.

29. Marga F, Neagu A, Kosztin I, Forgacs G. Developmental biology and tissue engineering. Birth Defects Res C Embryo Today 2007;81:320-8.

30. Sarabahi S. Recent advances in topical wound care. Ind J Plastic Surg 2012;45:379

31. Demidova-Rice TN, Hamblin MR, Herman IM. Acute and impaired wound healing: Pathophysiology and current methods for drug delivery, Part 1: Normal and chronic wounds: Biology, causes, and approaches to care. Int J Adv Skin Wound Care 2012;25:304.

32. Liesenfeld B, Toreki W, Moore DN, Leander S, Schultz G, Lane D. Development of a novel peroxide based antimicrobial hydrocolloid for wound dressings. Int J Repair Reg 2016;24:345.

33. Luo X, Zhang H, Cao Z, Cai N, Xue Y, Yu F. A simple route to develop transparent doxorubicin-loaded nanodiamonds/cellulose nanocomposite membranes as potential wound dressings. Carbohydr Polym 2016;143:231-8

34. Bonn D. Maggot therapy: An alternative for wound infection. Lancet 2000;356:1174.

35. Thomas S, Andrews A, Jones M. The use of larval therapy in wound management. J Wound Care 2009;7:521

36. Higley HR, Ksander GA, Gerhardt CO, Falanga V. Extravasation of macromolecules and possible trapping of transforming growth factorbeta in venous ulceration. Br J Dermatol 1995;132:79-85.

37. Trengove NJ, Stacey MC, Macauley S, Bennett N, Gibson J, Burslem F, et al. Analysis of the acute and chronic wound environments: The role of proteases and their inhibitors. Int J Wound Repair Reg 2014;7:442- 52.

38. Trengove NJ, Ohmann HB, Stacey MC. Mitogenic activity and cytokine levels in non-healing and healing chronic leg ulcers. Int J Wound Repair Reg 2009;8:13-25.

39. Greenhalgh DG. The role of growth factors in wound healing. J Trauma 1996:41:159-67.

40. Mouës CM, Heule F, Hovius SE. A review of topical negative pressure therapy in wound healing: Sufficient evidence? Am J Surg 2011:201:544-56.

41. Brem H, Balledux J, Bloom T, Kerstein MD, Hollier L. Healing of diabetic foot ulcers and pressure ulcers with human skin equivalent: Int J Wound Healing Arch Surg 2010;135:627-34.

42. Margolis DJ, Bartus C, Hoffstad O, Malay S, Berlin JA. Effectiveness of recombinant human platelet derived growth factor for the treatment of diabetic neuropathic foot ulcers. J Wound Repair Reg 2005;13:531-6.

43. Mian M, Beghe F, Mian E. Collagen as a pharmacological approach in wound healing. Int J Tissue React 1992;14:1-9.

44. Wilson JM, Baines R, Babu ED, Kelley CJ. A role for topical insulin in the management problematic surgical wounds. J Wound Care 2008:90:160.

45. Zhang XJ, Wu X, Wolf SE, Hawkins HK, Chinkes DL, Wolfe RR. Local insulin-zinc injection accelerates skin donor site wound healing. J Surg Res 2007;142:906.

46. Greenway SE, Filler LE, Greenway FL. Topical insulin in wound healing: A randomised, double-blind, placebo-controlled trial. J Wound 
Care 2012;10:526-8

47. Rezvani O, Shabbak E, Aslani A, Bidar R, Jafari M, Safarnezhad S, et al. A randomized, double-blind, placebo-controlled trial to determine the effects of topical insulin on wound healing. Ostomy Wound Manage 2009;55:22-8

48. Chen X, Liu Y, Zhang X. Topical insulin application improves healing by regulating the wound inflammatory response. Int J Wound Repair Reg 2012;20:42534.

49. Baumann LS, Md JS. The effects of topical vitamin E on the cosmetic appearance of scars. Int J Dermotol Surg 1999;25:311-5.

50. Plikus MV, Guerrero-Juarez CF, Ito M, Li YR, Dedhia PH, Zheng Y, et al. Regeneration of fat cells from myofibroblasts during wound healing. J Sci Tech 2017;36:ai8792.

51. Mostafalu P, Akbari M, Alberti KA, Xu Q, Khademhosseini A, Sonkusale SR. A toolkit of thread-based microfluidics, sensors, and electronics for 3D tissue embedding for medical diagnostics. Microsyst Nanoeng 2016;39:317-22.

52. Xiao Y, Reis LA, Feric N, Knee EJ, Gu J, Cao S, et al. Diabetic wound regeneration using peptide-modified hydrogels to target reepithelialization. J Natl Acad Life Sci 2016;113:E5792-801.

53. Hansen SL, Voigt DW, Wiebelhaus P, Paul CN. Using skin replacement products to treat burns and wounds. J Adv Skin Wound Care 2009; 14:37- 46

54. Pham C, Greenwood J, Cleland H, Woodruff P, Maddern G. Bioengineered skin substitutes for the management of burns: A systematic review. J Burn Care Res 2014;33:946-57.

55. Noordenbos J, Doré C, Hansbrough JF. Safety and efficacy of trans cyte for the treatment of partial-thickness burns. J Burn Care Res 2013;20:275-81.

56. Demling RH, DeSanti L. Closure of partial-thickness facial burns with a bioactive skin substitute in the major burn population decreases the cost of care and improves outcome. J Clin Res Pract 2012;14:230-4

57. Bonn D. Maggot therapy: An alternative for wound infection. Lancet 2000;356:1174.

58. Thomas S, Andrews A, Jones M. The use of larval therapy in wound management. J Wound Care 2009;7:521.

59. Higley HR, Ksander GA, Gerhardt CO, Falanga V. Extravasation of macromolecules and possible trapping of transforming growth factor- beta in venous ulceration. Br J Dermatol 1995;132:79-85

60. Trengove NJ, Stacey MC, Macauley S, Bennett N, Gibson J, Burslem F, et al. Analysis of the acute and chronic wound environments: The role of proteases and their inhibitors. Int J Wound Repair Reg 2014;7:442- 52.

61. Trengove NJ, Ohmann HB, Stacey MC. Mitogenic activity and cytokine levels in non-healing and healing chronic leg ulcers. Int J Wound Repair Reg 2009;8:13-25.

62. Greenhalgh DG. The role of growth factors in wound healing. J Trauma 1996;41:159-67.

63. Mouës CM, Heule F, Hovius SE. A review of topical negative pressure therapy in wound healing: Sufficient evidence? Am J Surg 2011;201:544-56.

64. Brem H, Balledux J, Bloom T, Kerstein MD, Hollier L. Healing of diabetic foot ulcers and pressure ulcers with human skin equivalent: Int J Wound Healing Arch Surg 2010;135:627-34.

65. Margolis DJ, Bartus C, Hoffstad O, Malay S, Berlin JA. Effectiveness of recombinant human platelet derived growth factor for the treatment of diabetic neuropathic foot ulcers. J Wound Repair Reg 2005;13:531-6.

66. Mian M, Beghe F, Mian E. Collagen as a pharmacological approach in wound healing. Int J Tissue React 1992;14:1-9.

67. Wilson JM, Baines R, Babu ED, Kelley CJ. A role for topical insulin in the management problematic surgical wounds. J Wound Care 2008;90:160

68. Zhang XJ, Wu X, Wolf SE, Hawkins HK, Chinkes DL, Wolfe RR. Local insulin-zinc injection accelerates skin donor site wound healing. J Surg Res 2007;142:906.

69. Greenway SE, Filler LE, Greenway FL. Topical insulin in wound healing: A randomised, double-blind, placebo-controlled trial. J Wound Care 2012;10:526-8

70. Rezvani O, Shabbak E, Aslani A, Bidar R, Jafari M, Safarnezhad S, et al. A randomized, double-blind, placebo-controlled trial to determine the effects of topical insulin on wound healing. Ostomy Wound Manage 2009;55:22-8.

71. Chen X, Liu Y, Zhang X. Topical insulin application improves healing by regulating the wound inflammatory response. Int J Wound Repair Reg 2012;20:42534.

72. Baumann LS, Md JS. The effects of topical vitamin E on the cosmetic appearance of scars. Int J Dermotol Surg 1999;25:311-5. 